\title{
'Stop Calling it Aggression': War as Crime
}

\author{
Gerry Simpson*
}

\section{Introduction, and Some Comments \\ on Jones and Milling}

... invasions have, since time immemorial, been a violation of international law... (United States v von Weizsacker et al (1949)). ${ }^{1}$

In the past two decades there has been a revival of interest in international criminal law. This renaissance has been stimulated by war crimes trials in the Balkans, Sierra Leone, Cambodia, Tanzania, and Iraq, as well as by the establishment of the world's first permanent international criminal court in Rome in 1998. In this paper I want to make three arguments about a particular, and perhaps idiosyncratic, project within this field: namely, the attempt to criminalize war itself.

First, I want to offer an explanation for a conundrum. In 1946, the International Military Tribunal at Nuremberg placed the crime of aggression at the heart of the de-nazification project. The judgment contains -one of the most famous phrases in war crimes history:

To initiate a war of aggression, therefore, is not only an international crime; it is the supreme international crime differing only from other war crimes in that it contains within itself the accumulated evil of the whole. ${ }^{2}$

But if the crime of aggression was the supreme crime in 1945 (the International Criminal Tribunal for Rwanda in the Serushago declared genocide to be the 'crime of crimes' in 1998), why is it that there have

* This essay is based on, and draws on, a recent book, Law, War and Crime: War Crimes Trials and the Reinvention of International Law, published by Polity Press, Cambridge in 2007.

1 Quoted in Rv Jones and Milling [2006] UKHL 16 per Bingham J. at para 12, <http:// www.publications.parliament.uk/pa/ld200506/ldjudgmt/jd060329/jones-1.htm> (accessed 27 August 2008).

2 IMT Judgment 1948, 'The Common Plan or Conspiracy' para 4 at <http:/www.yale. edu/lawweb/avalon/imt/proc/judnazi.htm> (accessed 27 August 2008). 
been no international prosecutions of the crime since 1948 and indeed little agreement on the scope and content of that crime in that period? ${ }^{3}$ It is worth remembering in this context that without a crime of aggression at Nuremberg there would be no crime of genocide. Both historically and jurisdictionally, the allied concern with the Holocaust was parasitic on Germany's invasions of Poland and Czechoslovakia. Historically, it is unlikely that a territorially confined German genocide would have provoked a world war, and the IMT Charter reflects this in its jurisdictional provisions. Crimes against humanity (encompassing acts of genocide committed inside Germany) fell within the Tribunal's jurisdiction only if such crimes were committed in connection with or in execution of one of the (presumably) core crimes i.e. war crimes or the crime of aggression. The original Article 6, in fact, had not made this link explicit for crimes against humanity. The most famous semi-colon in history was removed by a protocol replacing it with a comma and at the same time making crimes against humanity subsidiary to the crime of war.

If crimes against humanity and, by implication, the crime of genocide were mired in jurisdictional debate, the position of aggression was reinforced by its inclusion as the first-named crime in Article 6, and by the weighting it received in the charges made against the high-ranking Nazis at Nuremberg, and, in particular, the Japanese leadership at Tokyo. Given all this, how did international law move from the certainties of aggression's position as the crime of crimes in Article 6 of the IMT Charter to the tentativeness of Article 5(2) of the Rome Statute for the International Criminal Court? By 1998, after all, the delegates at Rome could merely agree on the following weak provision: 'The court shall exercise jurisdiction over aggression once a provision is adopted in accordance with articles 121 and 123.'

My explanation for this apparent move from the confident repression of war in 1946 to the procedural frustrations of 1998 revolves around

3 Prosecutor $v$ Serushago (Case No. ICTR-98-39-S) Sentence, 5 February 1999, para. 15.

4 A Protocol signed shortly after the establishment of the Tribunal states: 'a discrepancy has been found to exist between the originals of Article 6, paragraph (c), of the charter in the Russian language, on the one hand, and the originals in the English and French languages, on the other, to wit, the semi-colon in Article 6, paragraph (c), of the Charter between the words 'war' and 'or', carried in the English and French texts, is a comma in the Russian text, and whereas it is desired to rectify this discrepancy: Now, Therefore, the undersigned, signatories of the said Agreement on behalf of their respective Governments, duly authorized thereto, have agreed that Arricle 6, paragraph (c), of the Charter in the Russian text is correct, and that the meaning and intention of the Agreement and Charter require that the said semi-colon in the English text should be changed to a comma'. This, then, surely is one of the more consequential grammatical errors in history. 
five conceptions of international order, each of which is in some respects inimical to the whole idea of criminalizing aggression. The existence of these conceptions and the anxieties they contain, perhaps, explains why the ICC working groups and preparatory committees on aggression have laboured so hard, and so far without success, to reach a final definition of aggression. ${ }^{5}$

Second, towards the end of the essay, I want to advance some reasons, independent of these five anxieties, why we might hesitate before making war a crime. Why is it that even leftish liberal progressives who dislike war might decide there are better ways to resist war than through the concept of aggressive war? So, when Danilo Zolo asks in a recent article in the Journal of International Criminal Justice: 'Who's afraid of punishing aggressors?' I want to suggest that we might want to answer: 'We are'.

Third, and this theme runs through the piece, I explore (though only very superficially) a sense I have that the crime of aggression is caught between two sets of contradictory urges or intuitions about war and peace. In one case, we think of international crime as collective or social on one hand, and personal and individual on the other. It strikes us as unsatisfactory to say that individuals commit wars of aggression when we know such wars require the support of a state apparatus (Eichmann in Jerusalem) or popular sentiment (Hitler's Willing Executioners) or military culture (Ordinary Men). ${ }^{7}$ Blaming the state, though, raises the spectre of Versailles and collective responsibility, and fails to accord with our visceral and more morally attractive inclinations to punish individuals. To put it another way, neither of the prevailing metaphors works; it is accurate only - in a loose sense to say that 'Hitler invaded Poland in 1939' but the idea that 'Germany invaded Poland in 1939' seems no better.

The second tension or set of contradictory beliefs is marked by a tendency to view war as crime and at the same time think of it as a radical solution to problems of social evil; this tension is apparent in prevailing liberal attitudes to, say, the war in Iraq as against possible unilateral action in Darfur (each illegal under a standard reading of the UN Charter). I will say a little more about this in the next section.

5 See the work of the ICC Special Working Group on the Crime of Aggression at <http://www.icc-cpi.int/asp/aspaggression.html> (accessed 27 August 2008).

6 Danilo Zolo, 'Who's Afraid of Punishing Aggressors?: On the Double-Track Approach to International Criminal Justice' 5(4) Journal of International Criminal Justice (2007) 799-807.

${ }^{7}$ H. Arendt, Eichmann in Jerusalem: A Report on the Banality of Evil (1994); D. Goldhagen, Hitler's Willing Executioners, (New York: Knopf, 1996); C. R. Browning, Ordinary Men: Reserve Police Battalion 101 and the Final Solution in Poland (New York: Harper Perennial, 1992). 
By way of introduction, though, I begin by considering a relatively recent case handed down by the House of Lords in which some of these matters were ventilated. Is war a crime? Margaret Jones and Paul Milling thought so. Or, at least they thought the war on Iraq was a crime. So they did what any decent citizen would do and set out to prevent the commission of the crime. It is a defence to a charge of assault or trespass that the offence was committed in order to prevent a greater crime. Breaking a fellow shopper's leg is lawful if the shopper is about to shoot the girl at the check-out. This is sometimes referred to as the defence of necessity or reasonable force. On $13 \mathrm{March}$, a date poised neatly between the AtrorneyGeneral's two written opinions on the legality of the Iraq War, Ms Jones and her accomplices broke into Fairford Airbase in Gloucestershire and disabled some military equipment, including fuel tankers and bomb trailers. $^{8}$ They were charged with criminal damage. The appeal came before the House of Lords in 2006. Three questions were deemed pertinent by the House: is aggression a crime under international law? was this war a crime under international law? and, critically for the Law Lords, is war a crime under English law?

The House of Lords held that inter-state aggression is not a crime under domestic law but, reversing the decision of the Court of Appeal, that aggression is a crime under international law. ${ }^{9}$ The House made no finding on the Iraq War. For the House of Lords, war can be a crime, at least when it is aggressive war.

Five points are worth making here. First, the House was focused, correctly, on the ius ad bellum. The defence of necessity related to the crime of aggression, not to any alleged crimes carried out by UK forces in Iraq. ${ }^{10}$ These have been the subject of several courts martial (Payne et al) and a long-running civil claim under the European Convention on Human Rights and the UK Human Rights Act (Al-Skeini). ${ }^{1}$ None of this has any relevance to the question of aggression. The crime of war and crime in war

${ }^{8}$ R $v$ Jones and Milling, note 1 above, para. 3

9 Ibid, e.g. Bingham J. at para 12-19; see, too, for a discussion of the carlier ruling: R. Cryer, 'Aggression at the Court of Appeal' 10(2) Journal of Conflict and Security Latw, (2005) at 209-230 available at SSRN: <http://ssn.com/abstract $=915644>$ (accessed 27
August 2008).

10 The ius in bello (the law of war) as it applied to war crimes was not wholly absent from the proceedings but the focus of the Law Lords' reasoning was the crime of aggression.

11 Al-Skeini v Secretary of State for Defence [2007] UKHL 26; G. Simpson, 'The Death of Baha Mousa' 8(2) Melboume University Journal of International Law (2007) 340-355 $R \nu$ Payne, General Court Martial Charge Sheet (2006), available from < htcp://www.army. mod.uk/apa/courts_martial_trials $>$ at 18 October 2007. 
have long been regarded as separate categories. To kill in battle in support of an aggressive war is not a crime, to murder in a lawful war is.

Second, the House confirmed a disjuncture between national space, and international space. Thus an act regarded as a crime under international law is not a criminal offence in English law unless and until it has been incorporated into English law by Parliament. This is why we have the rather puzzling outcome in this decision: for the Lords, the crime of aggression is a crime everywhere, except in England.

Third, the House failed to recognize that the doctrine of aggression has a far more equivocal history than the neat trajectory drawn by the Lords. To be sure, the tribunals at Nuremberg and Tokyo both charged defendants with crimes against peace (12 individuals were convicted of this charge at Nuremberg) but this 'crime' has fallen off the radar since then. Yes, the General Assembly endorsed the Nuremberg Principles in 1946 but--and to paraphrase a great Scottish jurist, James Lorimer (describing Grotius) - having laid down these principles, the international community failed to pick them up again. ${ }^{12}$ It failed in 1954, when the General Assembly was unable to get the Soviets and the USA to agree on a definition of aggressive war (there was no such thing as aggression, only Soviet or American aggression), and it failed in 1998 when the states of the world left Rome having created a criminal court with jurisdiction over a broad range of offences but not aggression. ${ }^{13}$

Fourth, and most centrally for the purposes of this essay, the story of this whole project of criminalizing war is the story of a war that is aggressive but not here, not now, not in this court, or not until the Security Council has acted, or not until we have reached agreement at some working group. War as crime is a project in a state of perpetual deferral. And the reason we end up with this deferral is that the desire to criminalize aggression and war co-exists with a fantasy about war as a radical solution to social and political evil. The project I want to speak about is located at the heart of these contradictory urges. To take a typical progressive move in relation to war, we want to deplore the invasion of Iraq in 2003 and support the attack on Kosovo and Serbia in 1999 but we worry that perhaps we cannot do both, and at the same time (in any defensible way) criminalize aggression.

12 General Assembly Resolution 95(I), 11 December 1946 ('The Nuremberg Principles').

13 Draft Code of Offences against the Peace and Security of Mankind (1954) at <http:// untreaty.un.org/ilc/texts/instruments/english/draft\%20articles/7_3_1954.pdf $>$ (accessed 27 August 2008). 
Fifth, and finally, it may be that the whole concept of aggressive wat can be understood only in the context of two processes of juridification to which I now wish to turn.

In a recent book I have published called Law, War and Crime: War. Crimes Trials and the Reinvention of International Law, my ambition was to capture the field of war crimes trials; in orher words, to see it as a whole and not as a set of doctrinal propositions, or a scattering of institutions; or a code of crimes. The result was a series of relationships (maybe even dialectics) that seemed to me to mark or define the field. Whatever one was doing, as a participant in international criminal law (developing procedure, inventing institutions, executing heads of state), one seemed to be engaged in, or with, these relationships or tensions. Aggressive war was part of this story because it was a miniaturized version of some of war crimes law's struggles. It existed at the pointy end of a debate over law's subjects: was aggression structural or personal (e.g. Chapter Three of the book)? It was heavily implicated in the question of law's politics, the relationship between matters of international politics that transcended law, and matters that were transcended by law (e.g. Chapter Two). It raised doubts about whether, given the structure of international society, trials of aggressors could ever be anything other than show trials or a form of victor's justice (e.g. Chapter Five). And finally, it provoked questions about the limits and the feasibility of juridifying certain political spaces (e.g. Chapter Six).

In this next section, then, I introduce the rest of the essay by situating the crime of aggression in the context of what I call the juridification of diplomacy or law's hegemony (this being a reference to law's hegemonic tendencies to cover every field it encounters). But the problem of law and politics is most visible in the field of war and law, and the sharp end of this problem is the criminalization of war. Public international law, it might be argued, had two great achievements after the Second World War: one was the criminalization of atrocity committed during war (e.g. Article 147 of the Fourth Geneva Convention, 1949), the other was to render war itself illegal (e.g. Article 2(4) of the United Nations Charter). The criminalization of war, then, can be viewed as politics' last bastion, a point of greatest resistance. Why, though, have international lawyers embraced this project with such fervour (Section Two)? And what is the relationship between the criminalization of aggressive war and other forms of what Judith Shklar called 'tribunality' (Section Three)? ${ }^{14}$

14 Judith Shklar, Legalism (Boston, Mass: Harvard University Press, 1964) (passim). 


\section{Juridifying Law}

\section{Turning to tradition}

International lawyers are caught between two impulses vis-à-vis orher lawyers. ${ }^{15}$ One is to claim a close relationship to domestic law, the other is to emphasize how interesting it is to work at some distance from conventional Austinian forms of legality. The first claim varies in style and ambition. In ambitious versions of this approach, it is argued that international law bears a very close resemblance to national law in its institutional characteristics, in its textual concerns, and in its interpretative dilemmas. Inevitably, this approach leads to a court-directed mode of professional practice. This can either be centred on the use made of international law by domestic courts (literal domestication) or on the way international law is performed by tribunals such as the International Court of Justice (domestication by analogy). Thus a whole cadre of international lawyers, sometimes also scholars in high standing, treat international law as a series of judicial opinions to be discussed, debated, and disseminated. An international law conference or a conversation between international lawyers would then be largely indistinguishable in tone and subject matter from a similar conference or conversation among, say, property lawyers or tort lawyers. There would be the same gossipy familiarity with judicial personalities, the same doctrinal struggles, and the same potential for insulation from sociat structure and political contestation. Importantly, though, international law could then be studied and performed in forms identical to that of national law. Questions of enforcement and authority would be largely sidelined as 'sociology' or 'theory'.

\section{Turning to compliance}

The second position involves making a break with the domestic analogy, and has tended to prevail among international lawyers who wanted to show that H. L. A. Hart was wrong to say that international law was a primitive or inchoate simulacrum of authentic law. ${ }^{16}$ The retort to this argument involved asserting that international law was simply different. Naturally, the more different it was the better able were international lawyers to explain why it did not meet the self-referencing standards of

15 G. Simpson, 'On the Magic Mountain: Teaching Public International Law', 10(1) European Journal of International Law (1999) 70-92.

16 H. L. A. Hart, The Concept of Law (Oxford: Clarendon Press, 1961). 
legality imposed by theorists of national or domestic law. The trend, until very recently, was to adopt a posture of sophisticated resignation when confronted by the law/non-law argument (in response to which, Thomas Franck claimed international law was 'post-ontological'). ${ }^{17}$

The attention paid to judicial institutions by the first group simply played into the hands of Hartians who could then argue that these courts and laws, while formally similar, were pale imitations of real legal institutions. According to the second group, then, this was the wrong way to go about defending the field. Instead, this group conceded that international law was quite distinct from national law and that the courts or treaties found in international law could not be equated with, and operated in a different way from, judicial institutions or contracts in domestic law. The emphasis here, then, was on non-judicial forms of law: the practice of states, official statements by government representatives, the work of institutions, the persuasive effects of rule making, the habit-forming effects of rule following. Alongside these concerns was a tendency to de-emphasize the judicial, the textual, and the retributive. ${ }^{18}$

All of this was entangled in a set of arguments international lawyers wanted to make in response to International Relations scholars, too, who questioned the enterprise of international law from the analytical perspective. ${ }^{19}$ What was the point of studying these judicial forms if the material conditions of international politics dictated against their relevance? One answer to this seemed to lie in adopting a strong version of the first defence above in which legal institutions, and particularly judicial bodies, enforced international law in ways that were rather similar to the role played by such institutions domestically. And again, a second answer concentrated on de-emphasizing the apparent parallels between domestic legal institutions and their international counterparts and, instead, insinuating international law into the structure of international relations by bringing out its persuasive and identify-forming functions. 17 T. Franck, Fairness in International Law and Institutions (Oxford: Oxford University
Press, 1996).

18 T. Franck, The Power of Legitimacy Among Nations (Oxford: Oxford University Press, 1991).

19 Public international law, then, ended up occupying a borderland that was defined by the defences it mounted against two sets of arguments: international law was unenforceable as law and descriptively implausible as analysis. These defences were complicated by the ambivalent attitude of many IR scholars to international law's status. Law was at once intensely glamorous (treaty conferences, trials, cases in The Hague) and explicitly marginal. When it was glamorous it was marginal, when it came in from the margins (to do sociology or explanation) it became a poor man's international relations and lost its glamour (Simpson, 'On the Magic Mountain', note 15 above, 70-92). 
International law could be consensual, customary, non-hierarchical, and enforceable, albeit in a diffuse manner.

In the case of each 'defence', though, criminal law was either a rather foreign (in the first case) or inauspicious (in the second case) model for understanding the project of public international law. For those stressing the domestic analogy, private or civil law was the appropriate model. States were contractually bound to each other rather as individuals were in national legal orders. Courts (e.g. the International Court of Justice) operated as civil courts in which individual legal persons (states) settled their differences as equals and in the absence of a Leviathan. For those laying emphasis on the horizontal nature of international law, the absence of top-down enforcement was a virtue of the system. States could pursue their own ends only in the absence of the sort of overwhelming centralized power that seemed to be a requirement of a system of criminal justice. In any event, public international law precisely was an experiment in human relations that demonstrated the possibility of cooperation, collaboration, and sanction in the absence of criminal repression. To this extent, traditional international law was more in tune with a professional zeitgeist that was beginning to turn from retributive to restorative justice.

\section{Turning to enforcement}

Some lawyers, though, have turned their back on these conceptions of international law altogether (both the positivist, domestication version and the sociological version). Richard Goldstone takes this view to its " extreme when he says ' $[i]$ t seems to me that if you don't have international tribunals, you might as well not have international law' ${ }^{20}$ The proliferation of international criminal tribunals might be said to reflect this view. The establishment of, at least, three distinct genres of judicial institution-the permanent international criminal court, the ad hoc tribunals, and the hybrid courts - re-orients international law in the direction of Goldstone's thesis. This spasm of criminalization reflects trends in criminal justice generally. Andrew Ashworth has argued that '... what we see increasingly is the tendency to assume that the only satisfactory way to respond to some sort of anti-social conduct is to create a new criminal offence'. ${ }^{21}$

20 M. Scharf, Balkan Justice (1997).

21 A. Ashworth, 'Introduction' in A. Snare (ed.), Beware of Punishment, Scandinavian Studies in Criminology, Vol. 14. (Norway: Pax Forlag, 1995) at iii. On the other hand, 
There are, at least, a couple of reasons why the rise and rise of international criminal justice might be a decidedly mixed blessing for international lawyers (and especially those of a more sociological or political bent). First, international lawyers are embracing retribution in an era when commentators and practitioners working in, say, criminology or penology have serious problems with the whole idea of prison-based criminal law. ${ }^{22}$ International criminal lawyers may have hitched themselves to a dead horse. Second, in claiming that the law of war crimes somehow completes international law by giving it teeth, putting bad men in prison, and imitating domestic law's concreteness, international lawyers may be undercutting a lifetime of professional commitment to a different sort of legal order (lateral, non-hierarchical, non-coercive). ${ }^{23}$ The success or failure of international law now seems more bound up with irs capacity to secure convictions in criminal trials than in the everyday business of diplomatic engagement or functional treaty making. Even an event as fortuitous as the death of Milosevic now spells a period of remonstration against the inadequacies of an international legal order able neither to secure convictions nor eternal life.

\section{Juridifying Politics}

The second trend that accompanies the revival of international criminal law, and one in which this revival is thoroughly embedded, concerns the juridification of politics generally. There are two aspects to this. In this first case, powerful elites within Western states have sought to reconfigure political disasters (or what some international lawyers have called international crimes), such as the decision to invade Iraq, as administrative errors. In the second case, (political) enemies are converted into (war) criminals. In each case, political circumstance becomes legal process (either by cleansing the participants of political responsibility or by converting that political responsibility into crime).

international criminal law remains embryonic when contrasted with the typical W/cstern legal order. At the moment, the risks of over-criminalization remain smajl (I thank Rob
Cryer for this insight).

${ }^{22}$ D. Roche, 'Truth Commission Amnesties and the International Criminal Courr', 45 British Journal of Criminology 565-81; Snare, ibid. ${ }^{23}$ F. Megret, 'Three Dangers for the International Criminal Court' XII Finnish Yearbook
of International Law (2003) 244. 


\section{Political catastrophe as administrative error}

I will focus largely on the latter process but I do want to give one example of what we might call administrative juridification. In 29 May 2003, the BBC flagship radio programme, Today, carried a report by one of its journalists, Andrew Gilligan, contending that the Blair Government and, in particular its Press Officer, Alistair Campbell, had 'sexed up' an intelligence document on the threat posed by the Ba'ath regime. Particular attention was given to the question whether the Government had inserted, demanded the insertion of, or encouraged the insertion of, a claim that Iraq could launch weapons of mass destruction in 45 minutes. The report led to a vicious dispute between the $\mathrm{BBC}$ and the Government, and culminated in the revelation that Dr David Kelly, an arms control expert at the MOD, had been Gilligan's source for the story. Kelly endured a brief but torrid time in the public eye, including an abject appearance at the Foreign Affairs Committee of the House of Commons, before being found dead in a wood near his home in Cambridgeshire. Kelly's fate set in train the events that led to the Government establishing, in July 2003, an inquiry under the stewardship of Law Lord, Brian Hutton, with the intention of investigating '...the circumstances surrounding the death of Dr Kelly'.

But what were these circumstances? Or, more problematically, what was the permitted ambit of reviewable circumstances? At one extreme was the view that this was simply a glorified Coroner's Report into the causes of Dr Kelly's death. All else was extraneous. ${ }^{24}$ The terms of referonce certainly made an effort to concentrate Hutton's mind in this regard, describing a number of issues that did not fall within the judicial remit (para 9). ${ }^{25}$ But for many of those queuing outside the Royal Courts of Justice, this was an inquiry into the war itself. Lord Hutton's job, in the eyes of the anti-war coalitions, and in the fears of the Government itself, was to put Her Majesty's Government on trial and convict it of bad, dishonest, illegal, and perhaps, even, criminal acts.

In the end, Lord Hutton told the nation that Dr Kelly had committed suicide (no one seriously believed he had not) and admonished the $\mathrm{BBC}$ so severely that both the Chairman of the Board of Governors, Gavyn Davies, and the Director-General, Greg Dyke, resigned. The Blair Government meanwhile was gently reprimanded for having released

24 D. Murray, 'Hutton-The Wrong Inquiry', Open Democracy, 29 January 2004.

25 The Hutton Inquiry (2004) at <http://www.the-hutcon-inquiry.org.uk/content/ report/> (accessed 27 August 2008). 
Kelly's name without warning Kelly himself, and for the misdemeanour of having exercised a 'subconscious' influence on the Joint Intelligence Committee's intelligence warnings. ${ }^{26}$

But the Hutron Report did not still the desire for judgment. How could it? Juridification attempts closure but the ambit of judicial enquiry is usually too narrowly construed to achieve it. Hutton concentrated his intellect on an important but, perhaps, not all-important matter: did the Prime Minister lie? This question was not really properly distinguished in the public mind from the larger query: did Iraq have usable weapons of mass destruction and, therefore, was the war justifiable or even lawful? In the end, juridification produced something rather technical and obscure. Amidst a rash of high-table concessions (from David Kay declaring that no weapons of mass destruction would be found ('we were mistaken') to Paul Wolfowitz describing the hunt for such weapons as a pretext), Lord Hutton brought down his report declaring that the Blair Government had made an innocent administrative mistake.

Only days after Hutton handed down his report, President Bush acceded to demands that be set up an inquiry into the intelligence received leading to the intervention in Iraq. Shortly after that, Blair entrusted senior civil servant Robin Butler with the same job in the UK. The very inquiries described earlier as 'impossible' were in the process of being convened. ${ }^{27}$

What do these processes tell us about (international) politics? Do they replace politics altogether? When George Bush announced the US inquiry he assured the nation that he wanted to know the full facts about what had happened (as if he was a judge being asked to chair a Royal Commission into the behaviour of some other branch of government). The inquiry was to report after the November 2004 elections because Bush did not want to 'politicize' it. ${ }^{28}$ 'This is a revealing phrase because at one level juridified diplomacy is precisely that: depoliticized politics. A judicial inquiry is surely an attempt to rise above politics or, at the very least, denude politics of controversy. Yet this displacement cannot achieve such a result. Even in domestic political life, some areas of dispute are incapable of judicial or quasi-judicial resolution. Depoliticization is impossible because, in some circumstances, there is only politics. Administrative

26 Jonathan Freedland, ('If it went to the West End they'd call it Whitewash', The Guardian, 29 January 2004) has argued that Hutton disregarded all evidence implicating the Government in anything more serious (e.g. Kelly's statement to BBC journalist Susan Watts that the 45-minute claim had 'got out of all proportion' or Alistair Campbell's diary entries outlining the demands he had made to change the intelligence dossier).

${ }^{27}$ See Murray, note 24 above. The Butler Inquiry (2004) at <http://news.bbc.co.uk/2/ hi/uk_news/politics/3892809.stm> (accessed 27 August 2008).

${ }_{28}$ The Melbourne Age, 8 February 2004. 
juridification takes law's technical-regulatory aspect and applies it to political difference in an effort to smooth it away. Thus, for a while, in British cultural life, responsibility for the Iraq War seemed to rest with elites at the $\mathrm{BBC}$ or the subconscious failures of the intelligence community: anyone other than those who had made the decision to invade.

\section{Enemies as criminals}

Ten years after the trial of Rudolf Slansky, the former General Secretary of the Czechoslovakian Communist Party, the defendant (executed at the end of his trial in 1953) was partially rehabilitated. Slansky was exonerated of having committed common crimes (for example, he had been accused of murder, among the plethora of indictments he faced) but he remained responsible for having made political and ideological errors. ${ }^{29}$ This decision effected a reversal of the trial's original purpose, which was to 'transform abstract political-ideological differences into easily intelligible common crimes'. ${ }^{30}$ The 1963 decision, then, seemed to resurrect a liberal notion of crime and politics that insisted on an apparent separation of the two.

Alongside the tendency to turn political catastrophe into administrative error (thereby using law to neutralize the 'crimes' of political allies), there is another tendency (of which the criminalization of aggression plays a major part) to criminalize our political adversaries because they are enemies (thereby, as in Slansky's case, using law to criminalize the mistakes of our enemies). For international lawyers, juridification, particularly through the criminal law, seems to promise completion for international law by placing at the centre of the field a project that most strongly resembles national law at its most emblematic. War is the difficult case because decisions to go to war are the essence of international political life and national political conflict. For these reasons, the criminalization of war, partly because it is associated with the criminalization of politics, has been one of the most fraught projects in the modern history of international law and relations.

The Belgian attempts to indict Sharon, Arafat, Castro, and Tommy Francks, and the 1998 extradition proceedings instituted in the case of General Pinochet, have raised the possibility that the criminal law could be applied to people with whom we have sharp political disagreements. ${ }^{31}$

G. H. Hodos, Show Trials (Westport, Conn: Praeger, 1987) 163.

30 Ibid, xiii.

31 I do not mean to suggest here that all these proceedings related to allegations without substance. 
This is the obverse of administrative juridification and has its latter-day antecedents in American political life where it seems natural to think in terms of impeaching the President rather than going to the bother of defeating him at the polls. Whether one is against Bush or Clinton, there is a temptation to criminalize the conduct of the President rather than merely deplore it. ${ }^{32}$ This approach peaked during debates about the war in Iraq. Many opponents of the war initially thought of it as something they were against (strategically or morally). This was followed by a displacement of the political by the legal. Suddenly, it was not enough to be against the war, one had to declare it illegal. Bur declaring it illegal seemed to have a natural consequence: President Bush and Prime Minister Blair were criminals and ought to be sent to The Hague to face justice. So, anti-war posters often announced that the war was immoral, illegal, and criminal: bad policy = jailed world leaders. ${ }^{33}$

\section{Criminalizing War}

At the international level, the move to criminalize war in this way has a rather complicated history. In this section I want to offer two versions of this history. In the first, From politics to law, the repression of aggression is narrated as part of a political transformation of the very constitution of international society. This transformation begins at Versailles with the arraignment of the Kaiser, and culminates at Nuremberg with Robert Ley's suicide. In the second version, From law back to politics, the same period is rendered in more equivocal, less 'Schmittian' terms, and prefigures the post-Nuremberg hesitancies around the effort to make war a crime.

32 While efforts to impeach Prime Minister Blair eventually foundered, in early june 2008, Dennis Kucinich, a democrat congressman from Ohio, introduced 35 arricles of impeachment against President Bush: see Articles of Impeachment (2008) at <http:// kucinich.house.gov/News/DocumentSingle.aspx?DocumentID=93581> (accessed 27 August 2008). See, too, for an early report on impeachment proceedings in the UK from 2004: 'Commons motion to impeach Blair gets go ahead', The Guardian at <http://www. guardian.co.uk/politics/2004/nov/19/uk.iraqI>.

${ }^{33}$ Around the time of the approach to the war, I was often asked in the media why, if the war was illegal, the International Criminal Court was not issuing indictments against Bush and Blair. There was an understandable conflation of illegality with criminality (I will discuss this in greater detail in the next section). Of course, I declared, it was inconceivable that Blair would have to appear in court to justify his actions. Wasn't it? But a few months later there he was in front of Lord Hutton (albeit not in a criminal trial) explaining the Government's justifications for going to war to an inquiry into the BBC's reporting of the Iraq War. 


\section{From politics to law}

An individual who, as leader or organizer, actively participates in or orders the planning, preparation, initiation or waging of aggression committed by a state shall be responsible for a crime of aggression. (Article 16, International Law Commission Draft Code on Crimes (1996)). ${ }^{34}$

It has long been a central part of the liberal legality that the legal order remains neutral among competing political preferences. The political choices to which an individual commits and the orientation a person adopts towards the system are, ideally, irrelevant to questions of criminal culpability. Of course, this conception of law has been rocked by successive critiques (by law and society scholars, by Marxists, and in critical legal studies scholarship). Criminologists, too, have argued that, at a structural level, the criminal law is a mechanism by which a political society protects itself from deviant behaviour or consolidates its own normative claims. As the Chinese proverb puts it, crime is a creation of the criminal law. ${ }^{35}$ What domestic societies have criminalized, among other forms of behaviour, is war. There is a war on war, or a criminalization of violent opposition to society.

International society has struggled to establish this idea of itself as a society to be protected from the outside. Prior to the 20th century, what modern international law knows as crimes against humanity or genocide were simply acts of murder, rape, or assault committed on a mass scale at the national level, or vile acts of war committed during armed conflict. In each case, punishment came in the form of action at the national level (if it eame at all). In cases where the criminal law was applied, it was applied by nätional courts since only states were capable of repressing such crimes. In the absence of international society, wars against 'international society' remained inconceivable. But, unlike war crimes or genocide, war could not be criminalized at the national level either because warring states did not belong to each other's societies. The whole idea of sovereign immunity or 'act of state' arises from this. States were barred from prosecuting or suing each other's official representatives (including heads of state) in their own domestic courts. War undertaken by one state could not be judged in another state's national courts. That would breach the principle of sovereign equality. But meanwhile, war could not be characterized as a

${ }^{34}$ ILC Draft Code on Crimes against the Peace and Security of Mankind at <http:// untreaty.un.org/ilc/texts/instruments/English/draft\%20articles/7_4_1996.pdf>(accessed 27 August 2008).

35 P. Allott, The Health of Nations (Cambridge: Cambridge University Press, 2002). 
breach of (international) society's norms since there was no such society (in a sense strong enough to sustain a criminalization of aggression).

In the 19th century, therefore, war was conceived of as an essentially political act. Lawyers played little role in deciding whether wars were advisable or legitimate. There was certainly no sense in which wars could be viewed as criminal. As Lord Bingham put it in $R v$ Jones, " $i] \mathrm{t}$ may, I think, be doubtful whether such wars [discussing wars of aggression] were recognised in customary international law as a crime when the 20th Century began' (para 12). ${ }^{36}$ This was an era in which Machiavelli, Richelieu, and von Clausewitz dominated strategic thinking about war and peace. Quincy Wright, in a survey of the pre-20th century position, called war '.. an event, the origin of which is outside of international law' ${ }^{37}$

Versailles, then, seemed to revolutionize war and crime, and lay the ground for a criminalization of war at Nuremberg. In a book entitled, Great Powers and Outlaw States, I traced the broad outlines of the transformation of the international order in the 20 th century from one in which states are treated as equals, with this equal status remaining unchanged by war or hostility, to one in which distinctions are drawn between states on the basis of their conformity to certain models of good government or alignment with particular political projects. ${ }^{38}$ This transformation had important consequences for the way in which war itself was understood. Previously viewed as a form of combat at the inter-state level with the combatants subject to certain rules of the game and accorded equal status, in the 20th century, sometimes, war became a matter of police action on the part of the 'international community' aimed at dissident states within international society. ${ }^{39}$

For Schmitt, the modern history of international law began at Versailles. The criminalization of Germany, for him, represented the moment when the international community's rise to self-consciousness coincided with the punitive treatment of its enemies. The Allies combined the self-righteous anger of the French and British with the zealous constitutionalism of the Americans to produce a settlement that treated Germany not just as a defeated adversary but a criminal state. This, in turn, prefigured the post-war scene almost 30 years later, and set the terms for the development of a distinctively 20 th century conception

36 Note 1 above.

37 Q. Wright, 'The Outlawry of War' 19 AJII. (1925) 76.

38 G. Simpson, Great Powers and Outlaw States (Cambridge: Cambridge University Press, 2004).

39 C. Schmitt, The Nomos of the Earth, in the International Law of the Jus Publicum Europeaeum (Ann Arbor, Mich: Telos Press, 2003). 
of international sociery. The creation of an international community required the identification of groups and states outside this community that, ideally, represented a threat to that community. The use of armed force by such states became 'aggression' rather than war. This, in turn, required a juridical effort to distinguish war from aggression. 'Pest control' had displaced war. Enemies became criminals.

At the same time, the pests who initiated wars had become individually responsible for crimes. This is Bert Röling, the Dutch judge at Tokyo, discussing his dissenting opinion on aggression in a wonderfully free-flowing interview with Antonio Cassese: 'The word 'crime' in international law is applied to concepts comparable to political crimes... where the decisive element is the danger rather than the guilt, where the criminal is really an enemy rather than a villain'. ${ }^{40}$ This transformation of the international order was given flesh-and-blood expression by Robert Ley, the head of the Nazi Labour Front, and one of the 24 Nuremberg accused. Just prior to his suicide on 24 October 1945, Ley expressed his outrage and indignation on the subject of war and crime: 'Stand us up against a wall and shoot us... well and good ... you are victors. But why should I be brought before a Tribunal like a c...c...c. I can't even get the word out'. ${ }^{41}$

\section{From law back to politics}

The word was 'criminal' and, after Nuremberg and Tokyo, the international legal order was to have some trouble getting the word out. The landmărks in the criminalization of war are found at Nuremberg, Tokyo, at the United Nations in the 1950s, 1970s and 1990s, and in the negotiations surrounding the inclusion of aggression as a crime in the ICC Statute in Rome in 1998. But if one is to present a more complete version of the complications surrounding and dogging the criminalization project, it is important to juxtapose against these efforts, the claims of those who believe evaluations and assessments of war belong outside the juridical sphere. These critics of the criminalization project can be divided into two camps (these are further subdivided later in the essay): political realists (who believe decisions about war and peace are a matter of strategic judgement and misjudgement) and legalists (including those who wanted to maintain the strict distinction between the ius ad bellum and the ius in bello) (see below).

This opposition between juridifying war and constraining (or protecting, in the case of legalists) law is a constituent relationship within the field.

40 B. Röling, The Tokyo Trial and Beyond (Oxford: Polity Press, 1991).

41 G. Sereny, Albert Speer: His Battle with Truth (London: Picador, 1996) 573. 
It is present from the outset in the deliberations of the Commission on the Responsibilities of the Authors of the War established by the Versailles Peace Conference to investigate the question of who was responsible for the First World War. ${ }^{42}$ The tension is there in the relarionship between the findings of the Commission and the intentions of its backers, and in the relationship between the Treaty of Versailles itself and the Commission Report. In Articles 227-230 the Treaty of Versailles established preliminary responsibility for the war. For the first time in history Article 227 introduced the idea that an individual leader could be held accountable for the decision to go to war. The Kaiser was to be prosecured for violations of international morality and the sanctity of treaties'. This clause, which did not appear in the US-German version of the Treaty, was included because the Allies had instilled in their populations a strong sense that the Kaiser was personally responsible for the war. A great deal of propaganda disseminated throughout the war personalized the conflict: Article 227 made good on this personalization process. However, the Commission, the first expert gathering on the question of individual responsibility for war, was not minded to accept this view of armed conflict (the Commission considered crimes against humanity and war crimes, too, but the focus here is on the crime of aggression). The Commission established to determine 'authorship' of the war in fact rejected the whole idea that wars could be authored. According to the majority, aggression was simply not an act capable of judicial determination. Indeed, it was not an 'act' at all but instead a consequence of social, political, and economic forces beyond the ken of any court or commission. ${ }^{43}$ The question of authorship was a matter for historians and statesmen, and not for courts (who were likely to be consumed by the question for several years).

In any event, the 'peacemakers' went ahead with plans to convene trials. ${ }^{44}$ These plans were undone by the Kaiser absconding to The Netherlands, and by the Allies' lack of territorial leverage over the defeated Germans (this is a history recounted in Chapter Two of Law, War and Crime). The inter-war years, though, were marked by a series of furcher attempts to criminalize war. The League of Nations Draft Treaty

${ }^{2}$ Commission on the Responsibilities of the Authors of the War on the Enforcement of Penalties, 14(1) AJIL (1920) 95-154.

43 A similar unease is expressed by the ICJ in DRC v Uganda (2005) at hittp:/ www. icj-cij.org/docked/files/1 16/10455.pdf> (accessed 27 August 2008) when, prior to making findings on the illegal use of force, it acknowledges the complex and tragic situation which has long prevailed in the Grear Lakes region' (para 26). Ihis unease is central to the Separate Opinion of Judge Kooijnans in the same case: '[i]s it possible to extract from this tangled web [of history] one element, to isolate it, to subject it to kegal analysis...??

(Separate Opinion, para 11).

it M. Macmillan, The Peacemakers (I.ondon: John Murray, 2001). 
of Mutual Assistance in 1923 declared aggressive war a crime as did The Geneva Protocol of 1924 (stating that wars of aggression violated the solidarity of the international community). The League's Assembly used the term 'crime' to characterize aggressive war in the preamble to a resolution prohibiting wars of aggression. These were very much in the manner of reform proposals from the margins, however. At the centre, the status of war was shifting, not in the direction of the criminalization of aggression but towards making war illegal or, at least, subject to forms of collective security. The League of Nations Covenant placed some limits on its exercise and aggressive wars were to be met by coalitions of force deployed under the terms of the Covenant. The Kellogg-Briand Pact (1928) meanwhile prohibited recourse to war as an aspect of foreign policy but did not refer to the crime of aggression. Indeed, Kellogg-Briand was so couched with reservations and ambiguities that it is unclear what sort of war could possibly fall foul of the Pact. In a Note of 18 July 1928, the United Kingdom warned that the Treaty could have no effect on British action in its Empire. ${ }^{45}$ Meanwhile, Mr Kellogg, the US Secretary of State, reminded the Senate that his Treaty had placed no restrictions on the right of self-defence (a right that was self-judging and applicable outside US sovereign territory). ${ }^{46}$

None of this (pace Schmitr) added up to the criminalization of war. Indeed, critics of the Nuremberg and Tokyo War Crimes Trials remarked that there was a distinct lack of precedents for the crimes against peace tried in the destroyed German and Japanese cities. ${ }^{47}$ Nevertheless, under the IMT Charter, and in the reasoning of the Tribunal itself, aggression was regarded as the 'crime of crimes'; the crime containing the 'accumu- lated evil of the whole'. It was, as Robert Jackson put it, 'the crime which comprehends all other lesser crimes'. ${ }^{8}$ 'The war had been conducted abominably by the German State. There was no shortage of 'standard' war crimes e.g. the massacre of foreign civilian populations, the shooting of POWs, and the use of slave labour. Crimes against humanity were introduced to cover the atrocities committed against Germans themselves (in particular, of course, German Jews). But all of this, in the Tribunal's eyes, was largely a product of one over-arching scheme to wage a war of

45 United Kingdom Government, Further Correspondence respecting the US Proposal for the Renuniciation of War, Cmd. 3109 (1928) available at <http://www.yale.edu/lawweb/ avalon $/ \mathrm{kbpact} / \mathrm{kbbr}$.htm> (accessed 27 August 2008).

46 R. Pal, Crimes in International Relations (1955) 241.

47 R. Minear, Victor's Justice (Princeton, NJ: Princeton University Press, 1971); J. N. Maogoto, War Crimes and Realpolitik (Boulder, Col: Rienner, 2004).

48 B. Röling, 'Separate Judgement', in J. Pritchard (ed.) Tokyo War Crimes Trials (New York: Garland, 1999) vol 109: 11. 
aggression. As I have indicated earlier, the jurisdictional requirements articulated in Article 6 meant that convictions for crimes against humanity could only be secured if these crimes were committed in connection with the war of aggression or war crimes. Robert Jackson conceded that this requirement was included in order to avoid scrutiny of Allied practices either in the colonies or in the southern states of the United States. The crime of aggression, then, was utterly central to the case at Nuremberg (as it was in Tokyo).

But Nutemberg arrived at a moment that was not particularly propitious to the idea of making aggression a crime. The discussions at San Francisco had established a system under which engagement in illegal wars would be met by overwhelming force from a community-authorized coalition of states. There was no reference to the idea that criminality would attach itself to such breaches of international peace and security. Indeed, it was made plain in the Charter that the Security Council was to have absolute primacy in dealing with such threats (including, under Article 39, acts of aggression). This was a nod to a realist sensibility that had lost some faith in legalistic solutions to problems of international order. Writers like E. H. Carr and Hans Morgenthau were thoroughly disaffected by what they viewed as the misguided utopianism of inter-war advocates of treaties abolishing war or institutions that sought to tame human inclinations. It was simply naïve, they believed, to assume that diplomacy could be subject to legal resolution. In Shakespeare's Richard III, while Richard dissembles, plots, and prepares his bloody denouements, King Edward is congratulating himself on a good day's work bringing the many rivals within the court together in a compact. 'You peers continue this united league... I have made my friends at peace on earth' (Act II Scene 1). Richard himself ('determined to prove a villain') exploits this environment of treaties, peace, and law. When he comes upon the gathering of princes and dukes, he begins: 'A blessed labour, my most sovereign lord. Among this princely heap.... It is clear from his contemptuous tone that he intends to profit from this peace treaty (he does). The criminalization project seemed similarly doomed from the perspective of the postwar realists. Neville Chamberlain, with a subsequently unacknowledged prudence, may have been buying time at Munich but his agreement with Hitler, promising 'peace in our time', became emblematic of law's failures in this regard. Making war criminal (or relying on treaties) would not end wars, it would merely ensure that war's aggressors could work under cover of law and war's losers would fight to a bitter end. ${ }^{49}$

49 Lord Hankey, Politics, Trials, Errors (Oxford: Oxford University Press, 1450) 24. 
Robert Jackson and his associates forged ahead at Nuremberg regardless but this realist tendency inhibited the development of the permanent war crimes court he sought as well as the genuinely new sensibility in international relations and law he seemed to believe was necessary.

Meanwhile, at Tokyo, the tension between the juridifiers and the constraining realists was played out within the Tribunal itself. On one hand, there was the zealous abolitionism of Chief Prosecutor Keenan, on the other hand, there were three dissenting judgments from Justices Bernard of France, Pal of India, and Röling of The Netherlands. ${ }^{50}$

For Keenan, and, presumably, General MacArthur, the Tribunal's chief architect, the distinction between good and bad wars, or between publicly authorized wars and unauthorized ones, was central to the project. This distinction certainly changed the status of the adversaries but did it have any implications for the status of military personnel engaged in such wars? Keenan implied that in some cases the distinction between crimes of war and war as crime should be erased altogether. This was one of two famous efforts to effect this sort of shift (the other occurred during the 'war on terror' after 2001). In each case, there was enormous resistance from the legal and military establishments.

In Tokyo, Keenan suggested that all Japanese soldiers who had fought in the war in the Far East could be indicted for crimes against peace. ${ }^{51}$ According to him, to fight in an illegal war was to fight illegally. ${ }^{52}$ The Japanese had embarked on an aggressive war and '... since the war was illegal, all natural and normal results flowing from the original act are also illegal'. ${ }^{53}$ Chief Justice Webb agreed with Keenan. The logical conclusion of the aggressive war doctrine was that 'a soldier or civilian who opposed war but after it began decided it should be carried on... was guilty of waging aggressive war. ${ }^{54}$ The majority rejected this approach, arguing that it defied the whole structure of an international law of war based on a distinction between ius ad bellum and ius in bello.

After the attack on the Twin Towers, and the war on Afghanistan, lawyers in the US Justice Department embarked on a similar effort in relation to Taliban (and al Qaeda) forces. In the Gonzales Memo, the Chief Legal Counsel to the White House argued that the illegality of the war conducted by the Taliban (Afghanistan was a failed state, it was engaged in terroristic activities) meant that Taliban personnel (detained

so $\mathrm{R}$. Cryer and N. Boister, The Tokyo International Military Tribunal: A Reappraisal (Oxford: Oxford University Press, 2008) 277-291.

51 Viscount Maugham, UNO and War Crimes (London: John Murray, 1951) 18-39.

52 Y. Dinstein and M. Tabory (eds), War Crimes in International Law (The Hague: Kluwer, 1996) 19.

53 Pritchard, note 48 above, 25.

54 Ibid, 7. 
at Guanránamo Bay) could be deprived of their rights under the Geneva Conventions. ${ }^{55}$ Again, the legal and military establishments cavilled at such changes to the existing structures of international law. ${ }^{56}$

Keenan was much less successful than Gonzales and the Justice Department lawyers but the rejection of this reading of the law of war and force was only one of the problems he encountered before a surprisingly independent bench at Tokyo. Justice Pal's dissenting judgment included an indictment of the criminalization of war, and recalled the American dissent at Versailles as well as prefiguring, albeit more stridently, doubts expressed (by Americans and others) during the Rome negotiations for an International Criminal Court. For Pal, the decision to prosecute the defeated Japanese for the crime of aggression exposed the trial as irremediably political. $\mathrm{Pal}$ argued that it was defeat rather than aggression that was being criminalized, that aggression was a political acr falling outside the ambit of legality, and that the lack of precedents in this case meant that the Japanese were being tried for commitring acts that were not crimind at the point of commission (a clear violation of the non-retroactivity rule in Western jurisprudence).

Pal's most important insight, though, was to connect international law to a project for stabilizing and securing existing power distributions within international sociecy. For him, the criminalization of aggression was simply a way of treezing the status quo. The criminal repression of territorial change was meant to ensure that the frontiers created by the original sin of colonial maldistribution would remain fixed by the legitimizing force of an international rule of law. The deepening juridification of war was intended to remove armed struggle from the repertoire of anticolonial, anti-Western political movements and states. Japan had demonstrated to the colonized peoples of Asia that the European powers were no longer militarily invincible. True, they had replaced one form of colonialism with another, but it seemed arbitrary to Pal that Japanese colonialism should be subject to criminal sanctions while European aggression over the past four centuries should be implicity endorsed under international law. The prosecution of the Japanese was an act of imperial hypocrisy. ${ }^{57}$

55 Alberto Gonzales, Memorandum for the President, Haynes, Par II, 25 January 2002, Torture Papers, 118 and at <http://news.findlaw.com/usatoday/docs/torture/gnzls12502 mem $2 \mathrm{gwb}$.html> and at <http://www.gwu.edu/ - nsarchiv/NSAEBB/NSAEBB 1 27/ 02.01 .25 .pdf $>$ (both accessed 28 August 2008).

5o The response of significant sectors of the US military law elite is outlined in L. Sales, Detainee 002 (Melboourne: Melbourne University Publishing, 2007) and P. Sands, Torrure Teram, (Harmondsworth: Penguin, 2008).

57 The Japanese leadership was being tried for acts of pre-emprive sclf-defence ( $P$ al) chat were regarded as much more acceprable by the Western powers in subsequen decades. In 
In this, he anticipated the little-publicized justifications offered by the Iraqi state when it invaded Kuwait, claiming that it was simply undoing arbitrarily-drawn imperial boundaries between Kuwait and Iraq that had been imposed by colonial administrators seeking to fragment Iraq.

Recalling the American delegation at Versailles, Pal maintained that '... the historic causes of the war simply defy legal judgement'. ${ }^{88}$ Wars, unlike acts of murder, but like most momentous political decisions, do not fit readily into a legal matrix. It is not at all clear, according to Pal, what is responsible for a particular act of war: economic depression? an alienated underclass? the scarcity of some prized good such as land or oil? Even if one was to identify a specific socio-economic or political cause, the question of then attributing individual criminal responsibility remained highly problematic. Quincy Wright, writing in 1925, argued that wars were more akin to diseases: "[i]n so far as wars cannot be attributed to acts of responsible beings, it is nonsense to call them illegal'. ${ }^{59}$ In short, according to Pal, the personalization of responsibility for war is likely to be arbitrary, counterintuitive, and accidental.

The courts at Nuremberg and Tokyo did not rely entirely on precedents for the criminalization of aggression or a judgement about ultimate causes of the war. Instead, they posited the existence of an international society whose existence and fundamental mores had been threatened by Japanese and German 'aggression'. Robert Jackson, after conceding that the Germans had breached no treaties with the United States, nonetheless claimed that the Nazi war was a war of aggression: '... an illegitimate attack on the international peace and order' ${ }^{60}$ The Tokyo court, too, seemed to concede the lack of precedents for its judgment, saying that there was no need to consider whether there had been a conspiracy to wage war in violation of specific treaties and assurances [i.e. law] because ' ... the conspiracy to wage war was already criminal in the highest degree'.

The solution to the absence of precedents created a separate problem, though, and it was one that Bert Röling took up in his dialogues with

1973, the United States had warned that it would regard any attempt to cut off oil supplies in the Middle East as an act of war and in 2002 the US National Security Strategy developed a theory of pre-emption that was not dissimilar to the Japanese justification for its invasion of, say, the Philippines. This pre-emption doctrine has survived the 2006 National Security Strategy: see S. Kadri, 'The Wrong Way to Combat Terrorism', Open Democracy, 3 May 2006.

58 R. Pal, Dissentient Judgment of Justice Pal (1953).

59 Wright, note 37 above; Minear, note 47 above, 59; Pal, ibid, 33.

60 R. Jackson, Report on the London International Conference on Military Trials, Department of State Publication 3080 (Washington, DC: Government Printing Office, 1949), 383-384. 
Antonio Cassese some decades after his dissenting judgment at Tokyo, ${ }^{61}$ Röling was uncomfortable with the charge of aggression levelled against the Japanese. The criminalization of aggression required a conception of international society against which this aggression was directed. According to Röling, in 1945 such a society simply did not exist. The sense of shared moral purpose, cultural affinity, and political direction necessary to the criminalization of sovereign behaviour were absent. ${ }^{62}$ There were neither existing precedents nor the existence of a moral or social consensus that would have rendered precedents unnecessary (this did not stop Röling
from supporting convictions in some cases).

The paradox in all this is that while Nuremberg and Tokyo may have been 'landmarks dwarfing the surrounding scene' they were also moments of ambiguity for the criminalization of aggression and the juridification of war. ${ }^{6.3}$ The defendants at Nuremberg had exploited an Achilles' heel in the Allied case: the Soviet invasion of Poland in 1939 and the MolotovRibbentrop Pact. Speer asked the Sovier prosecutors whether Russian diplomats had read Mein Kampf, and if they had, why they had entered into a treaty with Hitler. ${ }^{64}$ Soon, the prosecutors were avoiding matters that might embarrass the Soviets. It was well known to the prosecutors at Tokyo, too, (and something Roosevelt had agonized over, according to Richard Minear) that, though Japan was being charged with aggression towards the Soviet Union, it was the Soviets who, by declaring war on Japan in 1941, had breached the non-aggression treaty berween the two
countries.

These concerns are inevitable: the crime of aggression will be discomfiting for any state while the sovereign prerogative to make war remained fundamental to the system. At Nuremberg, the Tribunal avoided this problem by developing the crime of aggression in a way that made it highly specific to the Nazi state. The conspiracy charges were one way in which this was done. The crime of aggression was reworked into a norm applicable to states caprured by a vicious cabal of conspirators intent on regional or global domination. This had the virtue of being tailored to the Nazi case (though even here the fit was nor perfect) but the vice of being

61 B. Röling, 7he Tokyo Frial and Beyond (Oxford: Polity Press, 1993).

62 The USA, UK and France all agreed with Röling at different times during discussions around Nuremberg. See Mincar, note 47 above, $48-49$. ${ }^{63}$ See $\Gamma$. McCormack and $G$. Simpson, The Lau of War Crimes (Boston, Mass: Kluwer
Law International, 1996), Preface.

${ }^{64}$ M. Marrus, The Nuremberg War Crimes Trials: A Documentary History (Bedford/St
Martin's, 1997) 115.

${ }^{65}$ Minear, nore 47 above, 97 
inapplicable to ordinary cases in which force was employed in the international system. At Tokyo, meanwhile, the project involving the prosecution of leaders who embark on illegal wars was bruised by the scathing dissenting judgments and by the imperfections of the Military Tribunal's final judgment (e.g. its belaboured and unconvincing efforts to convict Japanese leaders for political decisions made in the 1920s).

All of the above (the realist objecrions, the awkward double standards, the problem of international society, the specificity and contingency of the charges laid against the Japanese and Germans) explains why, in relation to aggression at least, the Nuremberg Principles endorsed by the United Nations General Assembly in 1946 proved to be a far-fromdefinitive sign of the future development of international law. ${ }^{66}$

Of the three core crimes prosecuted at Nuremberg (war crimes, crimes against humanity, and the crime of aggression), the law of war crimes developed apace in military manuals, in the Geneva Conventions of 1949 , and in much domestic legislation (e.g. the UK Geneva Conventions Act 1957), and the category 'crimes against humanity' inspired a series of treaties ranging from the Genocide Convention in 1948 through to the Torture Convention and beyond. The crime of aggression, on the other hand, might have contained 'the accumulated evil of the whole', but it fell into the doldrums after Nuremberg and Tokyo. The General Assembly requested the International Law Commission (ILC) to draft a Code on Crimes against the Peace and Security of Mankind in the 1950s but there was no agreement about how to define the crime of aggression. The Assembly itself defined aggression in 1974 in the Declaration on Aggression but this document did not have the status of law. ${ }^{67}$ All of this led one eminent commentator to complain ' $[\mathrm{t}]$ he die had been cast in favour of politicization of aggression rather than juridicization'. ${ }^{68}$

The most serious blow to the juridification project came at the high point of the development of the law of war crimes generally. In the 1990 s, with the field in its pomp, tribunality was very much the policy choice $d u$ jour. The response to atrocities committed in Bosnia was the establishment of ineffectual 'safe havens' and some limited and prematurely truncated air-strikes directed at Serb targets. When these strategies failed, the international community turned to war crimes tribunals. The International Criminal Tribunal for the Former Yugoslavia was decreed

66 Note 12 above.

67 See, too, Declaration on Friendly Relations 1970 (General Assembly Resolution 2625); General Assembly Resolution 2131 (21 December, 1965).

68 C. Bassiouni, 'From Versailles to Rwanda', 10 Harvard Human Rights Journal (1997) 9. 
inco existence by a chastened Security Council in 1993, and the Council followed this with a similar measure (following an even more feckless initial response) after the Rwandan genocide of 1994 . Hybrid tribunals began to proliferate (in Sierra Leone, in Cambodia, and in East Timor). But what was most remarkable about all this was that the 'crime of crimes' was missing from the ICTY Statuce (and then, more explicably, from the various hybrid tribunals). It may be that the drafters of the Statute believed the wars in the Balkans were largely internal armed conflicts to which the crime of aggression was an irrelevance-if so, the inclusion of grave breaches of the Geneva Conventions, applicable at the time of the Stature's adoption only to international armed conflict, was a curious move. More likely, the Secretary-General and the Council simply believed either that aggression no longer had sufficient contemporary standing as a crime, or that its inclusion, as James O'Brien argued in the American Journal of International Law, would have 'involved the tribunal squarely in the political issues surrounding the conflict'. ${ }^{69}$

Coinciding with this renewed institurion-building vigour in the field of war crimes trials, three important ILC draft conventions were undergoing development. These, at least, seemed to promise the rehabilitation of the crime of aggression and the juridification of war. Alongside the continuing development of the ILC Draft Statute for an International Criminal Court, there were also draft Articles on State Responsibility (1996) and a Draft Code on Crimes Against the Peace and Security of Mankind (1996). In each case, the crime of aggression played a relatively prominent role. The ICC Draft Statute included the crime of aggression as one of the core crimes over which the ICC would have jurisdiction (Article 23), the Draft Code on Crimes, in Article 16, provides that ' $[\mathrm{a}] \mathrm{n}$ individual who, as leader or organizer, actively participates in or orders the planning, preparation, initiation or waging of aggression committed by a State shall be responsible for a crime of aggression', and the ILC's 1996 Draft Articles on State Responsibility enumerated, in Article 19, a list of acts, including aggression, for which a state would be held criminally liable.

Ten years later all that had changed. In Article 5(2) the Rome Starute expressly excluded aggression from the Court's jurisdiction until such time as a provision is adopted defining the crime and setting out the conditions under which the Court may exercise jurisdiction under it'. Meanwhile, the Draft Code had been quierly dropped from

${ }^{69} \mathrm{~J}$. O'Brien, The International 'Tribunal for Violations of Humanitarian Law in the Former Yugosiavia 87 AJIL. (1993) 639. 
the international agenda, and the ILC's Articles on State Responsibility were adopted in 2001 but without reference to the crime of aggression..$^{70}$ In the next, and penultimate, section, I want to synthesize some of the objections to the criminalization of aggression in order to show just how difficult it is to come to agreement on this question.

\section{Five Anxieties}

I honestly believe that every country ought to do what it wants to do... it is either proud of itself or less proud of itself. (Donald Rumsfeld, Hamburg Speech, 2004)..$^{71}$

Stop calling it aggression, $\mathrm{O}$, we hate that expression, we only want the world to know, we support the status quo. (Tom Lehrer, 'Send the Marines', That Was the Year that Was, 1965)

...the historic causes of the war simply defy legal judgement. (Justice Pal, Dissentient Judgment, Tokyo War Crimes Tribunal). ${ }^{72}$

I have argued in this essay that a constitutive relationship within the field of international criminal law is that between the criminalization of aggression, and the imperative to shear off crimes against peace into another field altogether: politics, history, conscience. I want to conclude this essay by, first, delineating the political and legal projects that, today, make up the 'question of aggression' under or in international law, and then skètching some final caveats to the juridification project.

There are significant interests that continue to agitate for the revival of crimes against peace as a category within international law. This can account for the, perhaps illusory, quest for a definitive answer to the problem of aggression at the various preparatory communications issued since the Rome Conference with a view to establishing a framework for the prosecution of aggression. ${ }^{73}$ There are completists who believe that the criminalization of aggression will make international criminal law whole (see 'Juridifying Law', above). For them, it makes little sense that war crimes or crimes against humanity are part of an institutional structure when the original or supreme crime is missing. Some of this is nostalgia for Nuremberg; some of it is part of a historical mission to make universal

70 ILC Articles on the Responsibilities of States for Wrongful Acts, 2000.

71 D. Rumsfeld, Hamburg Speech, Guardian Weekly, 19-25 February 2004.

72 Kopelman, E, 'Ideology and International Law: The Dissent of the Indian justice at the Tokyo War Crimes Trial', 23 NYU Journal of International Law of Politics (1991) 373; note 58 above.

73 PCNICC/2002/2/Add.2 (24 July 2002). 
what was applied selectively at Nuremberg and Tokyo (the German and Japanese delegations were keen supporters of the crime of aggression at Rome). ${ }^{74}$

Prominent NGOs, meanwhile, are enthusiastic about criminalizing aggression because this promises to be a powerful irritant in ongoing campaigns to embarrass over-extending Great Powers in a highly interventionist era. ${ }^{75}$ Crimes against peace can also be useful in the pursuit of particular political ends. This was particularly noticeable in efforts to portray President Bush and Prime Minister Blair as aggressors or criminals during and after the war in Iraq. The Great Powers themselves, of course, support the criminalization project, in the abstract. It is, after all, important to be on the side of those who wish to abolish 'unjustifiable' wars (it is also necessary that this project never come to fruition for reasons I will discuss shortly). ${ }^{76}$ Finally, there are lawyers who point to a body of declarations, resolutions, and jurisprudence that appears to establish the criminal status of aggression. This paper trail running from Nuremberg through to the UN General Assembly's 1974 Definition of Aggression seems to point in one direction only: the holy grail of a workable definition, institutional superstructure, and body of jurisdictional norms for the crime of aggression. The failure of the Rome delegates to include aggression must have been mystifying in the context of all of this.

But this resistance is less puzzling when one considers the opposition to the crime of aggression. This appeared at the Rome negotiations in a number of different guises. There were jurisdictional arguments about who should possess competence over aggressive wars, substantive arguments about whether aggression required an 'armed attack', and about what sort of justifications might act to legitimize a use of force, and more prudential arguments about whether aggression belonged in the Statute at all (given aggression's political nature and its potential to distupt the work of the Court).

Crimes against peace are controversial precisely because the use of force in international relations remains a sovereign prerogative that sovereigns are understandably unwilling to disavow entirely, and because of the structurally decentralized and morally heterogeneous nature of international

74 J. Persico, Nuremberg: Infamyon Trial (New York: Random House, 1995); B. Ferencz, An International Criminal Court (New York: Oceana Publications, 1980) xii.

${ }^{75}$ Having said that, The Coalition for an International Criminal Court was agnostic on this issue prior to the Rome negotiations.

76 See e.g. the attenuated definition of 'aggression' included in the Iraqi Special Tribunal Statute (2003) available at <http://www.hrcr.org/hottopics/statute/ $>$ (accessed 28 August
2008). 
society. This is why, ranged against the enthusiasts for criminalizing war, is a formidable group of non-believers. These can be divided into five: sovereigntists (who know a clear definition will only constrain states from using force in their own interests); new imperialists (who want to use force to advance universalizing, political programmes and know that criminalizing force will limit their capacity to do so); anti-imperialists (who worry that the criminalization of aggression is simply a mechanism for punishing resistance to new imperial projects); bistoricists (who believe that the historical causes of war prohibit legal reckoning (to use Pal's language)); and legalists (who worry that the structure of international society, and the opposition to criminalizing aggression produced by that structure, has resulted in an absence of the sort of precedents and clear definitions necessary to establish a crime of aggression).

These sceptics have appeared already in the narrative I offered in the preceding section of this essay. I now want simply to offer a brief taxonomy by way of systematizing some of these sceptical currents in international thought.

Briefly, sovereigntists argue that neither law not institutions have any place in the decisions of nation states when matters of core security are at sake. Dean Acheson, former US Secretary of State, adopted a variant of precisely this argument when he said, during the Cuban Missile Crisis, that:

[t]he power, position and prestige of the United States had been challenged by another state; and the law does not deal with such questions of ultimate powerpower that comes close to the sources of sovereignty. ${ }^{77}$

Whole attitudes of mind and bodies of thought are dedicated to this view that parts of the international order are anarchic or without law. This perspective has found widespread support in the media since 11 September 2001. It is a view apparently prevalent, also, within the Bush Administration. The United Kingdom House of Commons Select Committee on Foreign Affairs reported on their investigations in the United States in the following terms:

The impression we obtained from those with whom we discussed the question was that, instead of establishing first whether military action would be legal, the US would act first and then use international law to defend its action retrospectively if it were possible to do so. ${ }^{78}$

77 D. Acheson, 'Remarks', Proceedings of the American Society of International Law, 57th Annual Meeting (1963) 14.

${ }_{78}$ Select Committee on Foreign Affairs, Foreign Policy Aspects of the War against Terrorism, HC 384 at para. 221. 
Michael Glennon reports that Madeleine Albright, on being told by then UK Foreign Minister Robin Cook that British Foreign Offic lawyers were finding it hard to justify war in Kosovo, replied ' $[\mathrm{g}] \mathrm{et}$ new lawyers' ${ }^{79}$ According to this view, states are entitled to make their own judgements and mistakes in matters that go to the heart of state sovereignty? To criminalize the use of force in such circumstances merely offers the pro spect of unenforceable law or the criminalization of defear (rather than aggression). When Mark Kendall-Smith refused to serve in the war on Iraq in 2004, he was court-martialled and sent to prison. The Judge Advocate in that case, Jack Bayliss, told Kendall-Smith that he had seriously misunderstood the crime of aggression (it applied only to high-ranking officials) and that, anyway, his job was to carry out the policy of government, not to evaluate that policy for conformity with international law. ${ }^{80}$

This sovereigntist position has a long history in international relations. The US objections to the proposed trial of the Kaiser were founded on a form of sovereigntism. ${ }^{81}$ Morgenthau's and Carr's objections (discussed above) are familiar counterblasts against the prevailing legalisms after the Second World War. More recently, Phillip Bobbitt has put the statist position in robust, and tellingly gendered, terms: '... the move to war is an act of the state not of boys.... it is the state against whom the aggression has been mounted, typically, that makes the move to war'. He gives the example of Germany, Britain, and France in $1939 .{ }^{82}$

Crimes against peace, of course, were formulated to punish the imperial designs of the Japanese in East Asia and the Germans in Europe and Africa, after the fact. But other imperial projects were expressly excluded from the ambit of the tribunals in Tokyo and Nuremberg. Soviet territorial expansion in Central Asia and Eastern Europe, and European Empire in Asia and Africa were not subject to scrutiny by the Court. New imperialists are disturbed, not by the selectivity of this, but by the whole idea of criminalizing force, which they find jejune and unsatisfactory. The potential abuse of the category 'crimes against peace' lies in its potential to seriously imperil international society by seeking to criminalize the use of

79 M. Glennon, The Limits of the Law, Prerogatives of Power (London: Palgrave Macmillan, 2001) 178.

80 The reasoning in the case appears contradictory. Bayliss J is reported to have ruled that the legality of the invasion was irrelevant. But he makes legality absolutely central in stating: 'Legal Opinion may be divided as to the correctness or otherwise of the advice given by the Attorney-General. But when such advice has been given, members of the armed forces cannot go behind it.' Richard Norton-Taylor, 'RAF Doctor jailed for refusing to go to Iraq', Guardian Weekly, 21-27 April 2006 at 8.

81 See Commission on Responsibilities, note 42 above.

82 P. Bobbitt, Shield of Achilles (Harmondsworth: Penguin, 2003) 8. 
military force by key members of the international elite: '[a] nation ought to do what it wants to do' 83

It is explicit in the new projections of the Bush Administration and the Blair Government, that force must be used to pursue international order and justice. The US Government's 2002 National Security Strategy defended the rights of the United States to use pre-emptive force to confront its enemy, and the Prime Minister, in a 2004 speech to his Sedgefield constituency, called for the dismantling of the Westphalian system of international law prohibiting unauthorized force, in order that a muscular humanitarianism could be pursued. ${ }^{84}$ Robert Kaplan, a leading realist thinker in this imperial tradition, has named this a 'pagan ethos', one unconstrained by commitments to non-intervention, or law, or morality, or the predilections of the Security Council (as many such commentators pointed out during the Iraq war, if war was necessary, how would the disapproval of Cameroon make it unnecessary?). For them, the essence of leadership is the capacity to adapt to changing conditions and engage in flexible war-making. As John Gray puts it, '... this connection between peace and the possible use of force [is] a permanent feature of the human affairs' ${ }^{85}$ If Blair is right, and force will be necessary to end humanitarian catastrophe or prevent genocide (and in the absence of Security Council authorizations, or agreement on new laws of humanitarian intervention, or secure compliance with the Nuclear Non-Proliferation Treaty), then that force will have to be aggressive force (if, say, the 1974 Declaration is to be the basis for an understanding of aggression) ${ }^{86}$ If Kaplan is right, and the world is about to enter an anarchic phase, then force to protect economic interests or gain control of degraded resources will be an inevitable feature of this phase. ${ }^{87}$ What will be required is a more honest imperialism of the sort advocated by, say, Niall Ferguson.

83 Rumsfeld, note 71 above.

84 Robert Cooper, one of Blair's former advisers, has said: "The challenge to the postmodern world [the successful states] is to get used to the idea of double-standards. Among ourselves, we operate on the basis of laws and open cooperative security. But when dealing with more old fashioned kind of states outside the post-modern continent of Europe, we need to revert to the rougher methods of an earlier era - force, pre-emptive attack, deception, whatever is necessary to deal with those who still live in the 19th century world of "every state for itself".' 'The Postmodern State' in M. Leonard (ed.), Reordering the World (London: Foreign Policy Centre, 2002).

85 J. Gray, 'The Mirage of Empire', New York Review of Books, 12 January 2006, 4-8.

B6 Notwithstanding the failed attempts to get agreement on a doctrine of humanitarian intervention or the subordination of sovereignty to the law prohibiting genocide. See Report of Secretary-General's High Level Panel (2004).

87 R. Kaplan, Warrior Politics: Why Leadership Demands a Pagan Ethos (New York: Random House, 2002). 
Attempts to criminalize aggression will begin to look increasingly forlorn in this context. Either these definitions will be rejected as too expansive (therefore permitting the projection of almost limitless imperial force) or too utopian (thereby restricting the projection of this force). Richard Perle and David Frum are blunt proponents of the latter view: '... the UN must endorse our "inherent" right to defend ourselves against new threats.... if not, we should formally reject the UN's authority over our war on terror'. 88

Anti-imperialists, meanwhile, come to the same conclusion for opposite reasons. Justice Pal's jeremiads in Tokyo have influenced concerns that a juridical distinction between aggressive wars and legitimate wars will simply become a projection of Great Power preferences. During the negotiations in Rome, there were those who feared the inclusion of aggression might be bought only at the high price of giving the Security Council primary jurisdiction over the crime. Indeed, the original ILC Draft in 1996 did precisely this. Article 23 provided that the ICC would have jurisdiction over a crime of aggression only where the Security Council had already determined the existence of an act of aggression. This was consonant with the Charter but anti-imperialists worried that it would also mean that crimes against peace would be for other people.

As I indicated earlier, Pal's objections to the Tokyo War Crimes Trials were not simply anti-imperial, though. He took the view that the whole effort to define aggression and attribute responsibility for it was misguided and ahistorical. Lawyers were not ideally placed to make the sorts of judgement necessary to determine who started the Second World War. Historicists, then, like the Versailles Commission on the Responsibilities for Authorship of War, believe that the causes of aggression are a matter of politics and history, not a matter of law, or authorship, or personal, or state responsibility. For them states are Nietszche's cold-hearted monsters, or, as A. J. P. Taylor is reported to have said, 'statesmen make mistakes, they do not commit crimes': a formula neatly reversed by Lord Hoffiman when he stated that the defendants in Jones had to show that the war in Iraq was a crime as well as a mistake. ${ }^{89}$ This historicism is present in the warning issued by Churchill: 'War is too foolish, too fantastic, to be thought of in the twentieth century ... the interdependence of nations... the sense of public law have rendered such nightmares impossible... are you quite

88 Frum and Perle, $A n$ End to Evil (New York: Random House, 2003) 271.

89 Jones and Milling, note 1 above, para 44. 
sure? It would be a pity to be wrong. ${ }^{90}$ History, as Azar Gat has demonstrated, tends to make life difficult for legalists. ${ }^{91}$

Given this sort of opposition, it is no wonder, then, that even those who had begun to assume aggression would be included as a core crime, eventually came to believe that the problems of definition, the sharp disagreements over jurisdiction, the lack of precedents, and the anarchic structure of international relations, meant that jurisdiction over crimes of aggression would have to be deferred. This was the outcome articulated in Article 5(2). The disagreements aired at the various meetings held since the Rome Conference have rather confirmed this. The problems associated with defining aggression and providing a framework for it have multiplied. In a sense, and to return to Jones and Milling, the reasoning of Lord Bingham in arguing for the existence of a crime of aggression illustrates why there is so much controversy about whether it actually exists. In Bingham's opinion, there is heavy reliance on, amongst other items, inter-war preambles or condemnations that call aggressive war a crime but are not legally binding; treaties from the same period that are legally binding but do not make war a crime (e.g. the Kellogg-Briand Pact); General Assembly Resolutions that are neither binding on states nor purport to define the crime of aggression for the purposes of holding individuals accountable; various ILC draft codes that remain draft precisely because states could not agree on the definition of aggression among other crimes; and case law that describes the prohibition on the use of force as a norm of ius cogens but has nothing to say about the crime of aggression (e.g. in the Nicaragua Case). In the end Lord Bingham concludes with the following: '[i]t is unhistorical to suppose that the elements of the crime were clear in 1945 but have since become in any way obscure'. ${ }^{92}$

But perhaps the law was not clearly enunciated at Nuremberg and, worse, at the sometimes shambolic proceedings in Tokyo. The IMT in Germany seemed to think that it was self-evident that aggressive wars had always been condemned by the international community. But, other than gesturing to the conscience of mankind and a scattering of unsatisfactory norms, which were de lege ferenda at best, the tribunal was unable to adduce much in the way of treaty or customary support for this proposition. The differences expressed at the Special Working Group over 60

90 Quoted in Remarks by Secretary of Defense Donald H. Rumsfeld, Arlington National Cemetery, 28 May 2001, available at <http://www.defenselink.mil/speeches/speech. aspx?speechid $=361>$ (accessed 28 August 2008); see, too, R. Woodward, State of Denial (New York: Simon \& Schuster, 2006).

${ }_{91}$ A. Gat, War in Human Civilization (New York: Oxford University Press, 2006).

92 Jones and Milling, note 1 above, para 19. 
years on suggest that either Nuremberg's clarity has given way to obscurity or Nuremberg's obscurity has yet to be remedied. In the end, it was easier to apply the crime of aggression to the Nazis (world-hiscorical villains) than it is to ourselves (virtuous warriors). Thus is why universalizing Nuremberg's discretionary law-making has proved so tricky beyond a few well-meaning General Assembly resolutions and a startling amount of academic consensus. As the Court of Appeal put ir, inelegantly: 'It is difficult to see in these circumstances how it can be said that there is, accordingly, a firmly established rule of international law which establishes a crime of aggression which can be translated into domestic law, where there is no consensus as to an essential element of the crime' (quoted by Hoffman. J. in Jones at para 48).

Lord Hoffman responds to this by stating that the current disagreements relate to questions of jurisdiction and circumstance (para. 59) and not substance. But this is not quite the case: controversy extends to all sorts of substantive matter going to the heart of definition. In the end, of course, the matter is settled on justiciability grounds. In a phrase that may be somewhat deflating viewed from the perspective of legalists, Hoffman notes that '...the services of international lawyers are nor required.....'
(para. 94).

The conclusion some legalists reached was that the crime of aggression was no longer and perhaps never had been 'a firmly established rule of international law'.93 There simply was not enough certaincy or consensus. As Osama bin Laden is alleged to have said: '[For them] this is not a crime, but rather a debatable issue. They bombed Iraq and considered that a debatable issue."'94

\section{A Crime to Come?}

The existence of these five anxieties does not mean aggression will disappear from the international scene. Its repression through criminal law remains a central ambition in at least one conception of war and crime; and there are periodic reminders of its importance. When the Deputy Legal Adviser to the UK Foreign Office, Elizabeth Wilmshurst, resigned in protest at the Iraq War, she declared that the war would be not just a breach of Article 2(4) imposing civil liability on transgressors (there was

93 Rv Jones (Margaret) [2005] QB 259.

94 Quoted in full at <http://news.bbc.co.uk/1/hi/world/south_asia/1585636.stm> (accessed 28 August 2008). 
widespread support for that position) but an act of aggression (a much more controversial assertion). In the original 7 March Secret Advice from the Attorney-General to the Prime Minister on the Legality of the War in Iraq, the UK's chief legal officer suggested that a domestic case might be brought against the Prime Minister given that aggression was a crime under international law and therefore UK domestic law. ${ }^{95}$

Lord Bingham opens his judgment in Jones and Milling in the following ringing terms:

The immense, perhaps unprecedented, suffering of many people in many countries during the twentieth century had at least one positive result: that it prompted a strong international determination to prevent and prohibit the waging of aggressive war. ${ }^{96}$

And in the Democratic Republic of Congo v Uganda, the DRC's submission describes Ugandan activities in DRC as 'acts of armed aggression'."7

Yet, for all the potential relevance of the crime of aggression to these cases, neither court deemed the crime to be relevant to its findings. ${ }^{98}$ In both cases, there is a reluctance to juridify this aspect of political life. In Jones, Bingham held that aggression is not a crime under UK domestic law (he worries about the possibility that the tacit assimilation of the crime into domestic law (through "incorporation' by the Court) would

95 UK Attorney-General, Lord Goldsmith, Opinion on the Legality of Military Action against Iraq 7 March 2003 (para 34), available at <http://news.bbc.co.uk/1/shared/bsp/ hi/pdfs/28_04_05_attorney_general.pdf>; UK Attorney-General, Lord Goldsmith, Published Advice on the Legality of the Iraq War, 17 March 2003, available at <http://www. guardian.co.uk/world/2003/mar/17/iraq2>; UK Deputy Legal Adviser to the Foreign Office, Letter of Resignation, $18 \mathrm{March}$, 2003, available at <http://news.bbc.co.uk/2/hi/ uk_news/politics/4377605.stm> (all accessed 28 August 2008). The Iraqi Special'Tribunal has included a curiously parochial version of the crime in its Statute.

96 Note 1 above per Bingham J. at para 1.

97 Note 47 above, Decision, para 1, para 23.

98 Lord Bingham delivering the lead opinion in Jones concludes its examination of international law by saying: '... the core elements of the crime of aggression have been understood, at least since 1945, with sufficient clarity to permit the lawful trial (and, on conviction, punishment) of those accused of this most serious crime. It is unhistorical to suppose that the elements of the crime were clear in 1945 but have since become in any way obscure' (at para. 19). In fact, as I argue in the body of the essay, the core elements were not clear in 1945 and have become less so since then. In 1945, a highly specialized criminal trial was established for the purpose of trying defeated enemies. The lack of precedent value has become clear in the light of a 60-year period in which there have been no prosecutions of crimes against peace, a vigorous debate about the existence of the crime, and deep ideological disagreements about the compatibility of the international system and the criminalization of aggression. Lord Hoffman, in Jones, is in '... no doubt that [aggression] is a recognised crime in international law' but he can point only to the Nuremberg Judgment and Article 5 of the ICC (postponing the exercise of jurisdiction) as support for this proposition. 
'draw the courts into an area which, in the past, they have entered, if at all, with reluctance and the utmost circumspection' (para 30)). The waging of war may be criminal, the Court scares, but it also falls squarely within the political discretion of an execurive exercising its prerogative powers. ${ }^{99}$ In $D R C \nu$ Congo, the majority judgment, and one of the separate opinions, agonize over the justiciability of the question of force at issue in the case. In the end, the Court finds that Uganda has breached the ius ad bellum but it makes no finding at all about whether an acc of aggression has occurred. Even in the case of the findings on the use of force alone, the Court's views are framed by the realization that force is a highly charged socio-political matter not a single episode of aberrant bilateral relations (something that Justice Pal had emphasized in his dissent at Tokyo. ${ }^{100}$ ) Judge Kooijmans, in his Separate Opinion in DRCv Uganda, introduces his opinion with the following quotation:

'To explain the intervention of one State into the affairs of another is rarely simple or uncontroversial... Moreover, the results are likely to be tentative, partial, and complex, and therefore less than cotally satisfying. One is more likely to end with a "thick description" of a complex episode than a "scientific" explanation of a discrete social event. ${ }^{101}$

Juridification has its limits. Of course, the case for juridification has been powerfully argued. Indeed, there are appealing reasons to charge individuals with crimes against humanity, or war crimes, or torture. The Pinochet and Nuremberg precedents are important ones, for all their failings, and the sight of a former oppressor defending himself in court must often bring with it a cathartic sense of justice being, if not done, at least attempted. Yet this essay suggests that the juridification of war through the criminalization of aggtession has been a hugely controversial and chequered project. I want to end by briefly canvassing three further reasons why the idea of individual responsibility for war, in particular, ought, at the very least, to give us pause.

First, the juridification of war has fixated on questions of individual agency. This is hardly surprising. The criminal law is an exercise in abstracting motivation from social realicy, in removing events from context, and in substituting individual culpability for social or political

99 It may also be a crime (under the licason Act 1351), tor example, to oppose such a war by 'giving aid and confort to enemies.

100 DRC v Uganda, note 47 above; Pa 1 , note 58 above, 558.

101 DRC v Uganda, ibid, Judge Kooijmans, Separate Opinion at I (quoting J. P. Clark, 39 Journal of Modern African Studies, (2001) 262). 
responsibility. ${ }^{102}$ Indeed, a standard defence ploy in war crimes trials involves displacing personal guilt with systemic violence or malfunction. The Milosevic Trial was organized partly around this opposition with Milosevic himself emphasizing the structural and social catalysts of the war, and the prosecution working diligently to convict Milosevic and not the Serbian state. War crimes trials describe a world of bad men doing evil deeds. The problem is the man: 'no man, no problem' (to paraphrase Stalin). In the middle of 2005 , I switched on the news to hear that Osama bin Laden had just issued another vicious threat against civilians in the West. The speech was apocalyptic, personal, and retributive. President Bush's response was eerily symmetrical. Both of them envisaged a world in which the removal of individual enemies would clear the ground for new political projects. It may be a little bracing to collapse Bush, bin Laden, and the war crimes project but on occasion, each has displayed a disregard for history, for context, and for politics. ${ }^{103}$ This, of course, was the gravamen of the objections to crimes against peace made by the American delegation at Versailles, and by Justice Pal at Tokyo. It remains a potent and salutary one.

Second, juridification, in defining atrocity or war through law, may create equivalences that do injustice to the lived experience of human populations or rely on 'idiot rules' that are unresponsive to the nature of war or the character of particular wars. ${ }^{104}$ The criminalization of aggression might be too blunt a mechanism for dealing with the problem of force in international relations. The definitions in the 1974 General Assembly Resolution on Aggression or the ILC's 1996 Draft Code could potentially encompass interventions ranging from the Iraqi invasion of Kuwait in 1991, to the Vietnamese intervention in Cambodia (Kampuchea) in 1979, through the NATO bombing of Kosovo and Serbia in 1999. The sorts of idiot rules elaborated in these definitions seem over-inclusive

102 This has implications for human rights generally. The human rights movement is being pulled in two directions from its institutional, pragmatic, gradualist, incrementalist middle ground. One way is towards structure: the WTO, linking human rights and trade, rethinking poverty, and so on. The other is towards agency and the 'evil men' view of history: this is the international war crimes wing of the human rights project.

103 Each (and here the human rights movement is implicated, again) seeks to undermine sovereignty in some form. The revolution in international affairs, this piercing of the veil of sovereignty celebrated by Pinochet watchers, International Criminal Law advocates, and human rights workers is shared by neo-conservatives in Washington. To hear Richard Haass speak of suspending the sovereignty of outlaw states, or making it conditional on certain behaviour, is to see a former Bush official appropriate the language of the war crimes and human rights movements.

${ }_{104}$ Franck, Legitimacy, note 18 above; M. Koskenniemi, 'Letter to the Editors of the Symposium', 93 AJIL (1999) 351. 
judged against, say, the response of international lawyers to these acts (many found the intervention in Kosovo to be 'legitimate', but the Iraq war 'criminal'). More nuanced rules, of course, might be unworkable.

Third, and finally, crimes against peace supplant prudential, strategic, and moral judgement by drawing bright lines between acceptable and unacceptable behaviour. If decisions about war and peace are complex and compromised, then the criminalization of aggression promises a sort of anti-politics where responsible and responsive decision making is suspended in favour of the mechanical application of legal categories: was there a cross-border element? did the attack constitute 'armed force'? And this anti-politics has a more sinister aspect. The problem with crimes against peace is that, in the absence of clear standards and/ or shared values in international society, there is a tendency to criminalize our enemies because they are our enemies. Once a state has been described as an aggressor then all sorts of judgements can be suspended. Negotiation, diplomacy, the economic calculations of realism, the classic Westphalian assumptions about the equality of nations, and the sense that it must always be kept in mind that after a war we have sooner or later to live with our enemies in amity', all give way to the imperatives of punishment and retribution. ${ }^{105}$

In the end, the rhetoric of aggressive war will be utilized for precisely these ends but, as a legal category, it is more likely that aggression will be consigned to the class of a 'crime to come' because it can neither be defined and applied universally (it would embrace the actions of the Great Powers, it would require a thick description of which international law is incapable), nor removed altogether from the international agenda (it is mandatory to describe certain outlier states and their leaders as 'aggressors'). 


\section{University Library}

\section{- M M I N E R VA A gateway to Melbourne's research publications}

Minerva Access is the Institutional Repository of The University of Melbourne

Author/s:

SIMPSON, G

Title:

'Stop calling it aggression': War as crime

Date:

2009

Citation:

SIMPSON, G. (2009). 'Stop calling it aggression': War as crime. O'Cinneide, C (Ed.). Holder, J (Ed.). Current Legal Problems 2008, (1), pp.191-228. Oxford University Press.

Persistent Link:

http://hdl.handle.net/11343/30128 